\title{
Reducing Concentrations of Benzo(a)pyrene in Gas Phase Soot Particles by Using and Burning Water Fuel Emulsions
}

\author{
Kubat Kemelov ${ }^{1 *}$, Uran Maymekov ${ }^{2}$, Damira Sambaeva ${ }^{3}$, \\ Zarlyk Maymekov ${ }^{1}$ \\ ${ }^{1}$ Department of Environmental Engineering, Kyrgyz-Turkish Manas University, Bishkek, Kyrgyz Republic \\ ${ }^{2}$ Moscow Institute of Physics and Technology, Dolgoprudny, Russia \\ ${ }^{3}$ Institute of Mining and Mining Technologies, Bishkek, Kyrgyz Republic
}

Received: 23 July 2019

Accepted: 15 September 2019

\begin{abstract}
In this study, benzo(a)pyrene-water-oxygen systems were investigated in wide ranges of change of temperature value and initial components to predict in which conditions benzo(a)pyrene degraded into more harmful substances. Consequently, the thermodynamic parameters of the benzo(a) pyrene-water-oxygen system were calculated and the concentration distribution of carbon, hydrogen and oxygen-containing particles in the gas phase were established. Adding water into the system allowed decreasing of carbon and acetylene. These elements are the key elements of benzo(a)pyrene formation. According to this, the main parameter for reducing the concentration of benzo(a)pyrene in the gas phase was the water content in fuel oil within $10-15 \%$.

Determination of the concentration of benzo(a)pyrene in samples of flue gases of DKVR-4/13 and PTVM- 30M boiler units of the Teplokommunoenergo heating organization of Bishkek city was carried out by chromatographic method. Concentrations of benzo(a)pyrene were found to compare the product of burning ordinary fuel oil and water fuel emulsion. Homogenization of the fuel-air mixture by adding water to the fuel oil allowed us to obtain an inverse emulsion and reduce the concentration of benzo(a)pyrene in flue gases up to $62 \%$. According to this, a new process flowsheet of water fuel emulsions production was proposed for the heating organization.
\end{abstract}

Keywords: Benzo(a)pyrene, PAH, carcinogenic pollutants, soot, combustion processes

*e-mail: kubat.kemelov@manas.edu.kg 


\section{Introduction}

Pyrolysis of organic fuels in a gaseous phase leads to the release of a wide class of unburned hydrocarbons, and furthermore, in the combustion process heavier hydrocarbons such as polycyclic aromatic hydrocarbons (PAH) can be synthesized [1], which are able to group the benzene ring compound [2-6]. Generally, the formation of benzo(a)pyrene occurs in two main ways. It forms as a result of condensation of benzene rings [3] as well as during the decomposition of aromatic compounds into lighter ones and their further polymerization at high temperatures. The key element in the formation of benzo(a)pyrene is the propargyl radical $\left(\mathrm{C}_{3} \mathrm{H}_{3}\right)$, where two radicals form an aromatic ring. Benzo(a)pyrene is an intermediate fragment in the formation of condensed carbon as well, consequently, $\mathrm{C}_{20} \mathrm{H}_{12}$ during the formation process is adsorbed on the soot particles of flue gases and is gradually dispersed in the surrounding natural environment [7]. It especially occurs in the winter during heating periods [8-11].

In terms of environmental impact, the entire class of hydrocarbons are related to pollutants. A special place in this class is taken by benzo(a)pyrene $\left(\mathrm{C}_{20} \mathrm{H}_{12}\right)$, since benzo(a)pyrene (as well as some other PAHs) might cause cancer in living organisms and cell mutation $[12,13]$. According to this, maximum exposure limit
(MEL) and occupational exposure limit (OEL) are many times tougher than for any other hydrocarbon groups. Moreover, benzo(a)pyrene is proposed as an indicator for the carcinogenic fraction of these PAHs [14-16]. Getting into an organism of single PAH compounds, for example benzo(a)pyrene alone, does not occur without other PAHs being present [17].

Consequently, safety problems related to benzo(a) pyrene continue to remain actual and the development of effective ways to minimize benzo(a)pyrene in a technogenic environment is still unresolved [18-27]. Therefore, in this study the formation and degradation of benzo(a)pyrene in model conditions was calculated according to thermodynamic conditions. The prediction of the reaction kinetics of PAHs requires an accurate description of their thermochemical properties. Accordingly, physico-chemical modeling of the thermal degradation of benzo(a)pyrene in a wide range of temperature change of conversion medium, prediction and reduction concentration of toxic substances in the gas phase is an actual scientific challenge.

\section{Material and Methods}

In this study, thermodynamic data were used in order to simulate the benz(a)pyrene-oxygen-water
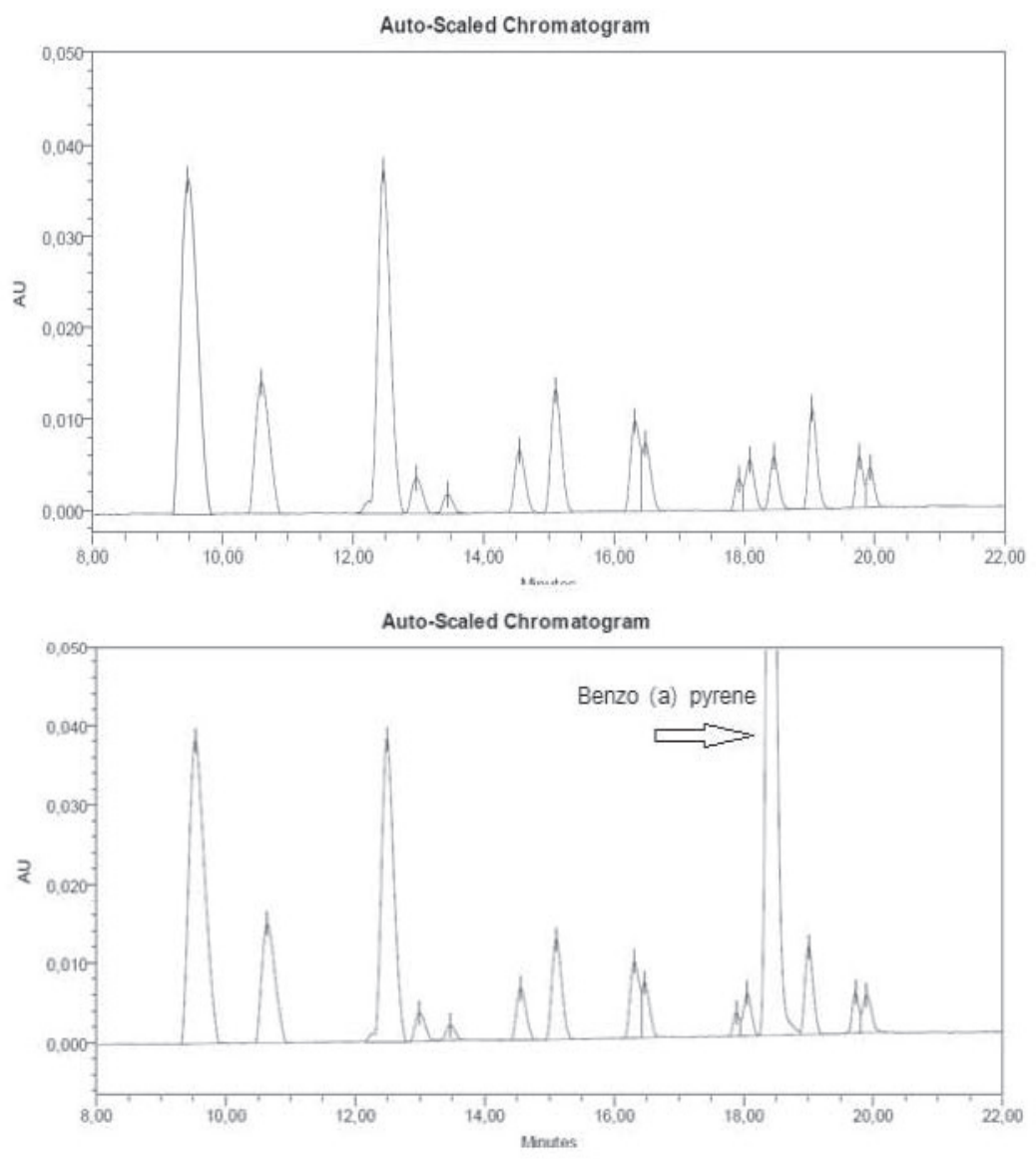

Fig. 1. Chromatogram of soot spiked with standard benzo(a)pyrene. 


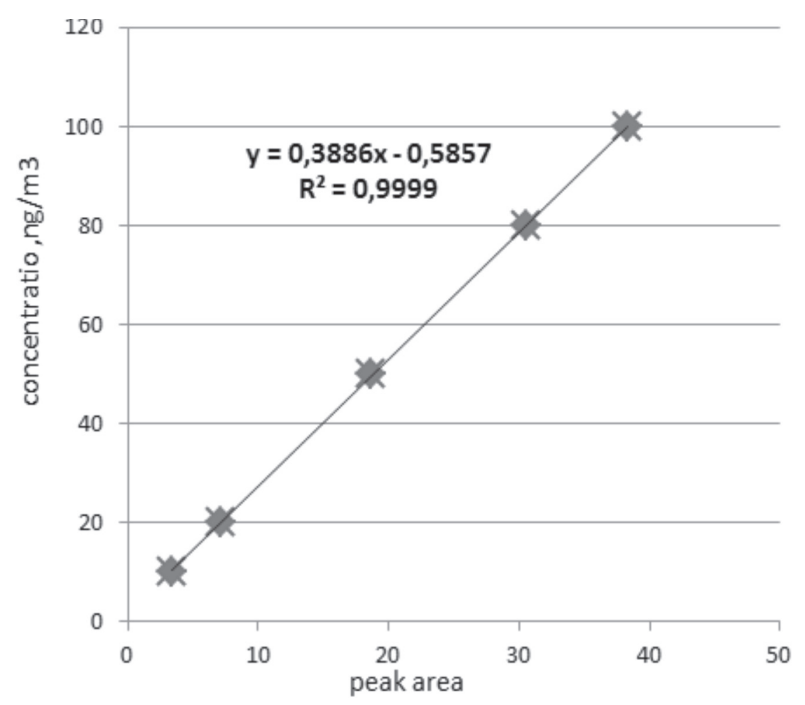

Fig. 2. Concentration of $\mathrm{C}_{20} \mathrm{H}_{12}$ versus peak area.

systems with the Terra software package program [28, 29], based on the principle of maximum entropy, which provided information on the energy and concentration characteristics of the components in a wide range of pressure $(\mathrm{P}, \mathrm{MPa})$ and temperature $(\mathrm{T}, \mathrm{K})$ change.

Identification and quantitative analysis of benzo(a) pyrene were performed by Waters 2690 Separations Module high-performance liquid chromatography (HPLC) with a Shimadzu RF 551 fluorometric detector using a Phenomenex C18 column $(250 \times 46 \mathrm{~mm})$. The column temperature was $25^{\circ} \mathrm{C}$. Injected sample volume was $25 \mu \mathrm{L}$. As a mobile phase, $60 \%$ acetonitrile and $40 \%$ water were used with a linear gradient to $100 \%$ acetonitrile. The flow rate was $1 \mathrm{~mL} / \mathrm{min}$. The data were collected and processed using the Waters Alliance Chemstation software and hardware complex [26, 29-33].

The determined peak of benzo(a)pyrene by adding a standard solution into the sample is shown in Fig. 1. Standard solutions for calibration were prepared and the peak area of each of them were obtained. The calibration curve was prepared using a relationship between the concentration of standard solution of benzo(a)pyrene and the chromatographic peak area (Fig. 2). Obtained linear equation was $y=0.3886 x-0.5857$, where $y$ is the concentration of benzo(a)pyrene $\left(\mathrm{ng} / \mathrm{m}^{3}\right)$ and $\mathrm{x}$ is the peak area. The correlation coefficient $\left(\mathrm{R}^{2}\right)$ was 0.9999 [29].

\section{Results and Discussion}

Benzo(a)pyrene-oxygen, benzo(a)pyrene-water, and benzo(a)pyrene-water-oxygen systems were studied at the entropy maximum. The thermodynamic parameters of the benzo(a)pyrene-water-oxygen system (Table 1) were calculated and it was shown that the values of total enthalpy $(\Delta \mathrm{I}<0)$ and internal energy $(\Delta U<0)$ were negative, which indicates that process of benzo(a)pyrene destruction occurs with the formation of low molecular weight components and particles (Table 2). The Prandtl number (Pr) identifies the ratio of kinematic viscosity to the diffusion coefficient in the gas phase (Table 1), which varies from 0.16 to 0.66 (according to the theory of gas dynamics $\operatorname{Pr}<1$ ). The adding of water into the $\mathrm{C}_{20} \mathrm{H}_{12}-\mathrm{O}_{2}$ system led to a radical decrease in condensed carbon (C) in the gas phase (Fig. 3): $\mathrm{C}=13,5602 \mathrm{~mol} / \mathrm{kg}$ at $500 \mathrm{~K}$; $\mathrm{C}=1 \cdot 10^{-30} \mathrm{~mol} / \mathrm{kg}$ at $2000 \mathrm{~K}$. Accordingly, the formation of condensed carbon and acetylene is practically not observed in $\mathrm{C}_{20} \mathrm{H}_{12}-\mathrm{H}_{2} \mathrm{O}-\mathrm{O}_{2}(1: 10: 1)$ system (Fig. 4, Table 3).

Table 2 shows the main products of the conversion of benzo(a)pyrene in the gas phase: $\mathrm{H}, \mathrm{H}_{2}, \mathrm{OH}, \mathrm{H}_{2} \mathrm{O}, \mathrm{O}, \mathrm{O}_{2}$, $\mathrm{C}, \mathrm{CO}, \mathrm{CO}_{2}, \mathrm{CH}_{4}$. Considering that polycyclic aromatic hydrocarbons (including benzo(a)pyrene) as one of the stages of the formation of soot, aromatic hydrocarbons convert into carbon black during combustion by direct condensation. Also, acetylene plays an important role (Table 3): $\mathrm{C}_{2} \mathrm{H}_{2}=4.05 \cdot 10^{-22}$ $\mathrm{mol} / \mathrm{kg}$ at $500 \mathrm{~K} ; 6.16 \cdot 10^{-9}, 1000 \mathrm{~K} ; 3.77 \cdot 10^{-10}, 1500 \mathrm{~K}$; $\left.1.03 \cdot 10^{-10}, 2000 \mathrm{~K} ; 5.04 \cdot 10^{-11}, 2500 \mathrm{~K}\right)$, as one of

Table 1. Change features of $\mathrm{C}_{20} \mathrm{H}_{12}-\mathrm{H}_{2} \mathrm{O}-\mathrm{O}_{2}(1: 10: 1)$ system, $\mathrm{P}=0.1 \mathrm{MPa}, \mathrm{T}=500-2500 \mathrm{~K}$.

\begin{tabular}{|c|c|c|c|c|c|c|c|c|}
\hline $\mathrm{T} . \mathrm{K}$ & $\begin{array}{c}\mathrm{V} \cdot 10^{2} \cdot \mathrm{m}^{3} / \\
\mathrm{kg}\end{array}$ & $\mathrm{S} . \mathrm{kJ} /(\mathrm{kg} \cdot \mathrm{K})$ & $\mathrm{I} . \mathrm{kJ} / \mathrm{kg}$ & $\mathrm{U} . \mathrm{kJ} / \mathrm{kg}$ & $\begin{array}{c}\mathrm{C} / \mathrm{p} \cdot 10^{4} \cdot \\
\mathrm{kJ} /(\mathrm{kg} \cdot \mathrm{K})\end{array}$ & $\begin{array}{c}\mathrm{Mu} \cdot 10^{5} \cdot \\
\mathrm{Pa} \cdot \mathrm{s}\end{array}$ & $\begin{array}{c}\mathrm{Lt}^{\prime} \cdot 10^{5} \cdot \mathrm{W} / \\
(\mathrm{m} \cdot \mathrm{K})\end{array}$ & $\mathrm{Pr}^{\prime} \cdot 10^{3}$ \\
\hline 500 & 208.1 & 10.6 & -11889.2 & -11973.3 & 22103.5 & 1.8 & 24183.9 & 165.0 \\
\hline 750 & 337.8 & 12.0 & -11021.1 & -11224.7 & 36633.9 & 2.7 & 85177.4 & 118.6 \\
\hline 1000 & 455.9 & 12.7 & -10392.8 & -10712.8 & 23477.7 & 3.5 & 13301.5 & 629.0 \\
\hline 1250 & 569.9 & 13.2 & -9791.1 & -10225.2 & 24594.9 & 4.2 & 16574.3 & 635.7 \\
\hline 1500 & 683.9 & 13.7 & -9164.4 & -9712.5 & 25531.9 & 4.9 & 19815.5 & 637.7 \\
\hline 1750 & 798.0 & 14.1 & -8514.1 & -9176.2 & 26525.7 & 5.5 & 23030.7 & 641.7 \\
\hline 2000 & 912.4 & 14.5 & -7833.2 & -8609.6 & 28163.3 & 6.1 & 26205.9 & 661.9 \\
\hline 2250 & 1028.6 & 14.8 & -7083.2 & -7975.6 & 32686.0 & 6.7 & 41206.2 & 532.7 \\
\hline 2500 & 1153.3 & 15.2 & -6114.3 & -7130.1 & 47771.2 & 7.2 & 83766.3 & 413.4 \\
\hline
\end{tabular}




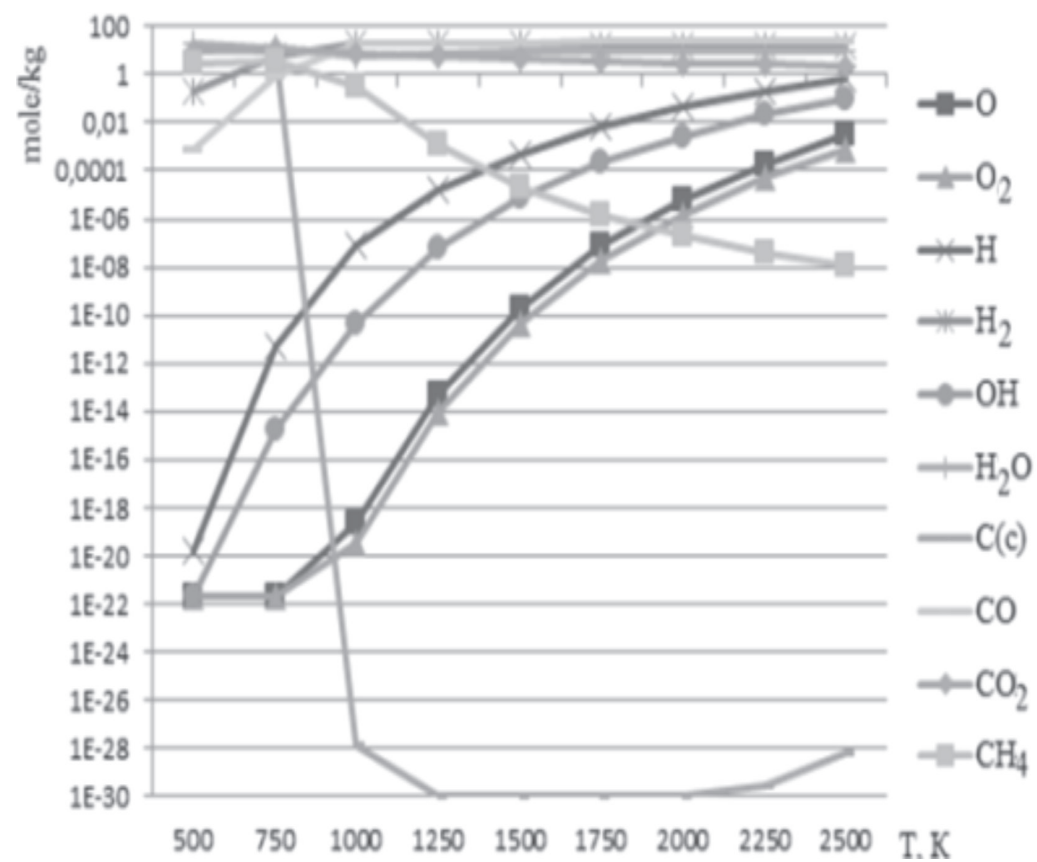

Fig. 3. Equilibrium composition and concentration of components, which occurs in the $\mathrm{C}_{20} \mathrm{H}_{12}-\mathrm{H}_{2} \mathrm{O}-\mathrm{O}_{2}(1: 1: 1)$ system.

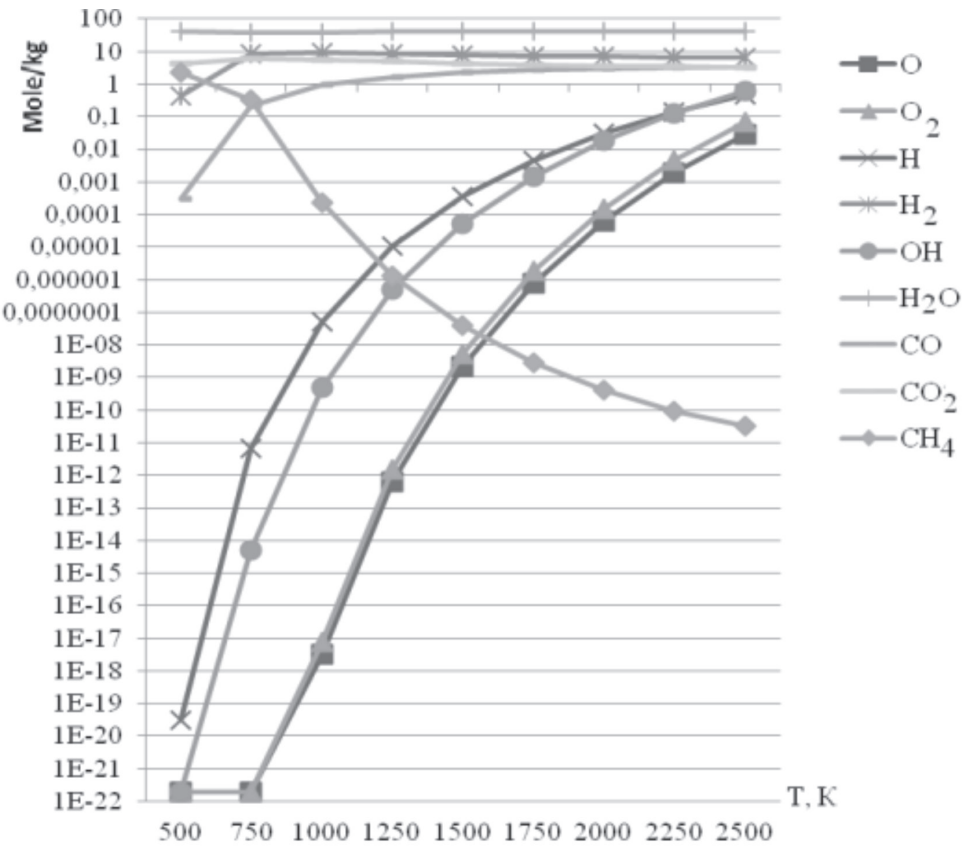

Fig. 4. Equilibrium composition and concentration of components, which occurs in the $\mathrm{C}_{20} \mathrm{H}_{12}-\mathrm{H}_{2} \mathrm{O}-\mathrm{O}_{2}(1: 10: 1)$ system.

the main elements included in the kinetic schemes for the synthesis of aromatic hydrocarbons.

Chemical mechanisms of soot formation using aromatic hydrocarbons containing fuels, the synthesis of benzo(a)pyrene comes in two ways: by condensation of benzene rings, and by polymerizing the pyrolysis products. In the second case, an important role is played by acetylene $(\mathrm{mol} / \mathrm{kg})$ as one of the main elements included in the kinetic scheme of synthesis of aromatic hydrocarbons [1, 6, 34-36]
Research on the mechanism of formation of benzo(a) pyrene during burning previously prepared water fuel emulsions showed that the level of concentration of the substance depends on the type of fuel mixture composition and the intensity of diffusion processes in the combustion zone $[6,8,21,37,38]$. For a given type of fuel, the main determining parameter was the mixture composition, which was characterized by excess air coefficient and the amount of water in the fuel [39-45]. 
Table 2. Equilibrium composition and concentration of components (mol/kg), which occurs in the $\mathrm{C}_{20} \mathrm{H}_{12}-\mathrm{H}_{2} \mathrm{O}-\mathrm{O}_{2}(1: 10: 1)$ system, $\mathrm{P}=0.1 \mathrm{MPa}, \mathrm{T}=500-2500 \mathrm{~K}$.

\begin{tabular}{|c|c|c|c|c|c|c|c|c|c|}
\hline \multirow{2}{*}{ Composition } & \multicolumn{9}{|c|}{ Temperature, $\mathrm{K}$} \\
\hline & 500 & 750 & 1000 & 1250 & 1500 & 1750 & 2000 & 2250 & 2500 \\
\hline $\mathrm{O}$ & $1.9 \cdot 10^{-22}$ & $1.9 \cdot 10^{-22}$ & $3.2 \cdot 10^{-18}$ & $6.2 \cdot 10^{-13}$ & $2.1 \cdot 10^{-9}$ & $7.5 \cdot 10^{-7}$ & $6.1 \cdot 10^{-5}$ & $1.8 \cdot 10^{-3}$ & $2.8 \cdot 10^{-2}$ \\
\hline $\mathrm{O}_{2}$ & $1.9 \cdot 10^{-22}$ & $1.9 \cdot 10^{-22}$ & $7.7 \cdot 10^{-18}$ & $1.4 \cdot 10^{-12}$ & $5.2 \cdot 10^{-9}$ & $1.8 \cdot 10^{-6}$ & $1.5 \cdot 10^{-4}$ & $4.7 \cdot 10^{-3}$ & $6.8 \cdot 10^{-2}$ \\
\hline $\mathrm{H}$ & $3.2 \cdot 10^{-20}$ & $6.7 \cdot 10^{-12}$ & $5.0 \cdot 10^{-8}$ & $1.0 \cdot 10^{-5}$ & $3.6 \cdot 10^{-4}$ & $4.6 \cdot 10^{-3}$ & $3.2 \cdot 10^{-2}$ & $1.4 \cdot 10^{-1}$ & $4.9 \cdot 10^{-1}$ \\
\hline $\mathrm{H}_{2}$ & 0.4 & 8.4 & 9.0 & 8.3 & 7.7 & 7.3 & 7.0 & 6.8 & 6.8 \\
\hline $\mathrm{OH}$ & $1.9 \cdot 10^{-22}$ & $5.2 \cdot 10^{-15}$ & $4.8 \cdot 10^{-10}$ & $5.0 \cdot 10^{-7}$ & $5.3 \cdot 10^{-5}$ & $1.5 \cdot 10^{-3}$ & $1.8 \cdot 10^{-2}$ & $1.2 \cdot 10^{-1}$ & $6.0 \cdot 10^{-1}$ \\
\hline $\mathrm{HO}_{2}$ & $1.9 \cdot 10^{-22}$ & $1.9 \cdot 10^{-22}$ & $4.5 \cdot 10^{-21}$ & $9.6 \cdot 10^{-16}$ & $3.6 \cdot 10^{-12}$ & $1.3 \cdot 10^{-9}$ & $1.1 \cdot 10^{-7}$ & $3.5 \cdot 10^{-6}$ & $5.2 \cdot 10^{-5}$ \\
\hline $\mathrm{H}_{2} \mathrm{O}$ & 43 & 39 & 39 & 39 & 40 & 40 & 41 & 41 & 40 \\
\hline $\mathrm{H}_{2} \mathrm{O}_{2}$ & $1.9 \cdot 10^{-22}$ & $1.9 \cdot 10^{-22}$ & $4.2 \cdot 10^{-17}$ & $2.4 \cdot 10^{-13}$ & $8.3 \cdot 10^{-11}$ & $5.4 \cdot 10^{-9}$ & $1.2 \cdot 10^{-7}$ & $1.5 \cdot 10^{-6}$ & $1.0 \cdot 10^{-5}$ \\
\hline $\mathrm{C}$ & $1.9 \cdot 10^{-22}$ & $1.9 \cdot 10^{-22}$ & $1.9 \cdot 10^{-22}$ & $1.9 \cdot 10^{-22}$ & $1.2 \cdot 10^{-20}$ & $1.1 \cdot 10^{-17}$ & $1.8 \cdot 10^{-15}$ & $9.3 \cdot 10^{-14}$ & $2.3 \cdot 10^{-12}$ \\
\hline $\mathrm{CO}$ & $3.0 \cdot 10^{-4}$ & 0.21 & 0.91 & 1.6 & 2.2 & 2.6 & 2.9 & 3.1 & 3.3 \\
\hline $\mathrm{CO}_{2}$ & 4.2 & 6.0 & 5.6 & 4.9 & 4.4 & 3.9 & 3.6 & 3.4 & 3.2 \\
\hline $\mathrm{CH}$ & $1.9 \cdot 10^{-22}$ & $1.9 \cdot 10^{-22}$ & $1.9 \cdot 10^{-22}$ & $1.9 \cdot 10^{-22}$ & $3.0 \cdot 10^{-19}$ & $6.4 \cdot 10^{-17}$ & $3.4 \cdot 10^{-15}$ & $7.7 \cdot 10^{-14}$ & $9.7 \cdot 10^{-13}$ \\
\hline $\mathrm{CH}_{2}$ & $1.9 \cdot 10^{-22}$ & $1.9 \cdot 10^{-22}$ & $4.2 \cdot 10^{-20}$ & $2.4 \cdot 10^{-17}$ & $1.4 \cdot 10^{-15}$ & $2.6 \cdot 10^{-14}$ & $2.2 \cdot 10^{-13}$ & $1.1 \cdot 10^{-12}$ & $4.6 \cdot 10^{-12}$ \\
\hline $\mathrm{CH}_{3}$ & $1.7 \cdot 10^{-18}$ & $3.8 \cdot 10^{-12}$ & $2.2 \cdot 10^{-11}$ & $3.3 \cdot 10^{-11}$ & $3.7 \cdot 10^{-11}$ & $3.8 \cdot 10^{-11}$ & $3.8 \cdot 10^{-11}$ & $3.8 \cdot 10^{-11}$ & $4.1 \cdot 10^{-11}$ \\
\hline $\mathrm{CH}_{4}$ & 2.3 & $3.0 \cdot 10^{-1}$ & $2.2 \cdot 10^{-4}$ & $1.3 \cdot 10^{-6}$ & $3.8 \cdot 10^{-8}$ & $2.9 \cdot 10^{-9}$ & $4.2 \cdot 10^{-10}$ & $9.6 \cdot 10^{-11}$ & $3.2 \cdot 10^{-11}$ \\
\hline $\mathrm{C}_{2} \mathrm{H}_{4}$ & $8.9 \cdot 10^{-13}$ & $9.7 \cdot 10^{-10}$ & $2.1 \cdot 10^{-12}$ & $1.6 \cdot 10^{-14}$ & $5.1 \cdot 10^{-16}$ & $3.9 \cdot 10^{-17}$ & $5.6 \cdot 10^{-18}$ & $1.2 \cdot 10^{-18}$ & $4.2 \cdot 10^{-19}$ \\
\hline $\mathrm{C}_{2} \mathrm{H}_{6}$ & $5.1 \cdot 10^{-7}$ & $1.2 \cdot 10^{-7}$ & $9.6 \cdot 10^{-13}$ & $2.2 \cdot 10^{-16}$ & $6.4 \cdot 10^{-19}$ & $9.0 \cdot 10^{-21}$ & $3.6 \cdot 10^{-22}$ & $1.9 \cdot 10^{-22}$ & $1.9 \cdot 10^{-22}$ \\
\hline $\mathrm{C}_{3} \mathrm{H}_{8}$ & $1.2 \cdot 10^{-12}$ & $2.4 \cdot 10^{-13}$ & $1.4 \cdot 10^{-20}$ & $1.9 \cdot 10^{-22}$ & $1.9 \cdot 10^{-22}$ & $1.9 \cdot 10^{-22}$ & $1.9 \cdot 10^{-22}$ & $1.9 \cdot 10^{-22}$ & $1.9 \cdot 10^{-22}$ \\
\hline $\mathrm{CHO}$ & $1.9 \cdot 10^{-22}$ & $1.4 \cdot 10^{-14}$ & $2.6 \cdot 10^{-11}$ & $1.6 \cdot 10^{-9}$ & $2.3 \cdot 10^{-8}$ & $1.5 \cdot 10^{-7}$ & $6.0 \cdot 10^{-7}$ & $1.7 \cdot 10^{-6}$ & $4.2 \cdot 10^{-6}$ \\
\hline $\mathrm{CHO}_{2}$ & $1.8 \cdot 10^{-21}$ & $1.8 \cdot 10^{-14}$ & $2.3 \cdot 10^{-11}$ & $1.4 \cdot 10^{-9}$ & $2.0 \cdot 10^{-8}$ & $1.4 \cdot 10^{-7}$ & $5.8 \cdot 10^{-7}$ & $1.7 \cdot 10^{-6}$ & $4.2 \cdot 10^{-6}$ \\
\hline $\mathrm{CH}_{2} \mathrm{O}$ & $2.3 \cdot 10^{-12}$ & $2.3 \cdot 10^{-8}$ & $8.6 \cdot 10^{-8}$ & $1.2 \cdot 10^{-7}$ & $1.4 \cdot 10^{-7}$ & $1.5 \cdot 10^{-7}$ & $1.5 \cdot 10^{-7}$ & $1.6 \cdot 10^{-7}$ & $1.7 \cdot 10^{-7}$ \\
\hline $\mathrm{CH}_{2} \mathrm{O}_{2}$ & $8.3 \cdot 10^{-9}$ & $5.3 \cdot 10^{-7}$ & $7.9 \cdot 10^{-7}$ & $8.2 \cdot 10^{-7}$ & $8.2 \cdot 10^{-7}$ & $8.2 \cdot 10^{-7}$ & $8.3 \cdot 10^{-7}$ & $8.4 \cdot 10^{-7}$ & $8.5 \cdot 10^{-7}$ \\
\hline $\mathrm{CH}_{3} \mathrm{O}$ & $1.9 \cdot 10^{-22}$ & $4.5 \cdot 10^{-20}$ & $1.9 \cdot 10^{-17}$ & $4.5 \cdot 10^{-16}$ & $3.3 \cdot 10^{-15}$ & $1.3 \cdot 10^{-14}$ & $3.9 \cdot 10^{-14}$ & $8.8 \cdot 10^{-14}$ & $1.7 \cdot 10^{-13}$ \\
\hline $\mathrm{C}_{2} \mathrm{H}_{4} \mathrm{O}_{2}$ & $2.7 \cdot 10^{-11}$ & $8.8 \cdot 10^{-11}$ & $2.5 \cdot 10^{-13}$ & $3.5 \cdot 10^{-15}$ & $1.8 \cdot 10^{-16}$ & $2.1 \cdot 10^{-17}$ & $4.2 \cdot 10^{-18}$ & $1.2 \cdot 10^{-18}$ & $4.7 \cdot 10^{-19}$ \\
\hline $\mathrm{O}_{3}$ & $1.9 \cdot 10^{-22}$ & $1.9 \cdot 10^{-22}$ & $1.9 \cdot 10^{-22}$ & $1.9 \cdot 10^{-22}$ & $1.9 \cdot 10^{-22}$ & $6.8 \cdot 10^{-22}$ & $5.5 \cdot 10^{-18}$ & $6.2 \cdot 10^{-15}$ & $1.6 \cdot 10^{-12}$ \\
\hline
\end{tabular}

Table 3. Calculation of the concentration of carbon, hydrogen, and oxygen-containing particles $(\mathrm{mol} / \mathrm{kg})$ in the gas phase during the destruction of the benzo(a)pyrene-water-oxygen system; $\mathrm{P}=0.1 \mathrm{MPa}, \mathrm{T}=500-2500 \mathrm{~K}$.

\begin{tabular}{|c|c|c|c|c|}
\hline Systems & $\mathrm{C}_{20} \mathrm{H}_{12}-\mathrm{O}_{2}(1: 1)$ & $\mathrm{C}_{20} \mathrm{H}_{12}-\mathrm{H}_{2} \mathrm{O}(1: 1)$ & $\mathrm{C}_{20} \mathrm{H}_{12}-\mathrm{H}_{2} \mathrm{O}_{2}-\mathrm{O}_{2}(1: 1: 1)$ & $\mathrm{C}_{20} \mathrm{H}_{12}-\mathrm{H}_{2} \mathrm{O}_{-} \mathrm{O}_{2}(1: 10: 1)$ \\
\hline $\mathrm{H}_{2}$ & $8 \cdot 10^{-2}-11$ & $0.3-38$ & $0.2-15$ & $0.4-6.8$ \\
\hline $\mathrm{H}$ & $9.2 \cdot 10^{-21}-0.5$ & $2.4 \cdot 10^{-20}-1.2$ & $1.8 \cdot 10^{-20}-0.7$ & $3.2 \cdot 10^{-20}-0.4$ \\
\hline $\mathrm{CO}$ & $6.0 \cdot 10^{-4}-31$ & $4 \cdot 10^{-4}-27$ & $7 \cdot 10^{-4}-23$ & $3 \cdot 10^{-4}-3.3$ \\
\hline $\mathrm{CO}_{2}$ & $10-8.8 \cdot 10^{-5}$ & $3.5-4.4 \cdot 10^{-5}$ & $9.7-2.5$ & $4.2-3.2$ \\
\hline $\mathrm{CH}_{4}$ & $0.7-4 \cdot 10^{-4}$ & $9.3-3 \cdot 10^{-3}$ & $3.1-1.2 \cdot 10^{-8}$ & $2.3-3.2 \cdot 10^{-11}$ \\
\hline $\mathrm{H}_{2} \mathrm{O}$ & $10-2 \cdot 10^{-4}$ & $20-3 \cdot 10^{-4}$ & $19-10$ & $43-40$ \\
\hline $\mathrm{C}_{2} \mathrm{H}_{2}$ & $1.9 \cdot 10^{-22}-0.1$ & $7 \cdot 10^{-22}-0.4$ & $4 \cdot 10^{-22}-5 \cdot 10^{-11}$ & - \\
\hline $\mathrm{C}$ & $28-8$ & $26-10$ & $13-5.7 \cdot 10^{-29}$ & - \\
\hline
\end{tabular}


Table 4. The ratio of atomic hydrogen-to-atomic carbon $(\mathrm{H} / \mathrm{C})$ in benzo(a)pyrene-containing systems; $\mathrm{P}=0.1 \mathrm{MPa}$.

\begin{tabular}{|c|c|c|c|c|c|c|}
\hline \multirow{2}{*}{ System } & \multirow{3}{*}{ Composition, mol/kg } & \multicolumn{5}{|c|}{ Temperature, $\mathrm{K}$} \\
\cline { 3 - 7 } & & 500 & 1000 & 1500 & 2000 & 2500 \\
\hline $\mathrm{C}_{20} \mathrm{H}_{12}-\mathrm{O}_{2}$ & \multirow{3}{*}{$\mathrm{H} / \mathrm{C}$} & $9.2 \cdot 10^{-21}$ & $4.2 \cdot 10^{-8}$ & $3.9 \cdot 10^{-4}$ & $3.6 \cdot 10^{-2}$ & 0.56 \\
\cline { 3 - 7 } & & $1.9 \cdot 10^{-22}$ & $1.9 \cdot 10^{-22}$ & $7.4 \cdot 10^{-16}$ & $1.3 \cdot 10^{-9}$ & $7.2 \cdot 10^{-6}$ \\
\hline $\mathrm{C}_{20} \mathrm{H}_{12}-\mathrm{H}_{2} \mathrm{O}-\mathrm{O}_{2}$ & $\mathrm{H} / \mathrm{C}$ & $3.2 \cdot 10^{-20}$ & $5.1 \cdot 10^{-8}$ & $3.6 \cdot 10^{-4}$ & $3.2 \cdot 10^{-2}$ & 0.49 \\
\cline { 3 - 8 }$(1: 10: 1)$ & & $1.9 \cdot 10^{-22}$ & $1.9 \cdot 10^{-22}$ & $1.3 \cdot 10^{-20}$ & $1.8 \cdot 10^{-15}$ & $2.3 \cdot 10^{-12}$ \\
\hline
\end{tabular}

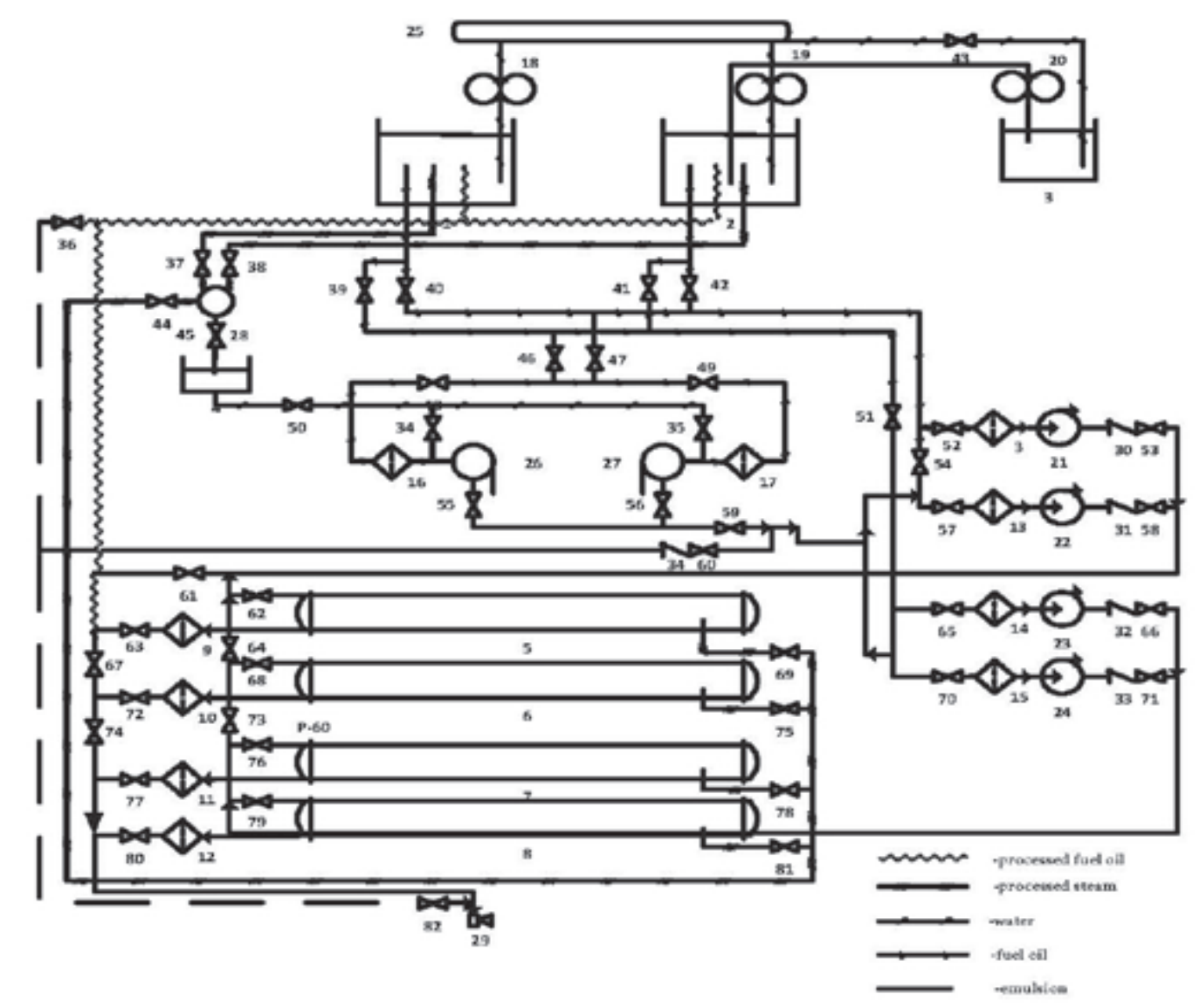

Fig. 5. Process flowsheet for the preparation and burning of water fuel emulsion in boilers of the type DKVR - 4/13 and PTVM - 30M: 1, 2 - tanks $\mathrm{V}=500 \mathrm{~m}^{3}, 3$ - pumped water tank, 4 - working water tank, 5-8 - heat exchangers, 9-17 - coarse filters, 18-19 - pumps for water pumping, 20 - pump for pumping fuel oil, 21-24 - working pumps, 25 - water collector, 26-27 - rotary pulsation apparatus, 28 - exhaust steam cooler, 29 - boiler nozzles, 30-34 - check valves, 34-35 - valves, and 36-81 - latches.

Table 5. Reduction of pollutant concentrations in the gas phase.

\begin{tabular}{|c|c|c|c|c|c|c|}
\hline \multirow{2}{*}{$\begin{array}{c}\text { Gas emission } \\
\text { components }\end{array}$} & \multicolumn{5}{|c|}{ Concentrations of harmful substances emitted into the atmosphere, $\mathrm{mg} / \mathrm{m}^{3}$} \\
\cline { 2 - 8 } & Fuel oil & Water fuel emulsion & Decreasing, $\%$ & Fuel oil & Water fuel emulsion & Decreasing, \% \\
\hline Sulfur dioxide & 372 & 352 & 5.3 & 341 & 320 & 6.1 \\
\hline Nitrogen oxides & 112 & 47 & 58 & 108 & 44 & 59.2 \\
\hline Carbon monoxide & 310 & 140 & 54.8 & 295 & 125 & 57.8 \\
\hline Hydrocarbon oil & 420 & 200 & 52.3 & 320 & 150 & 53.1 \\
\hline Soot & 55 & 21 & 61.1 & 30 & 14 & 53.3 \\
\hline
\end{tabular}


Table 6. Reduction of benzo(a)pyrene concentrations in the gas phase.

\begin{tabular}{|c|c|c|c|}
\hline \multirow{2}{*}{ The concentration of benzo(a)pyrene } & \multirow{2}{*}{ Type of fuel } & \multicolumn{2}{|c|}{ Boiler Units } \\
\hline & & PTVM- 30M & DKVR-4/13 \\
\hline $\mathrm{C}_{20} \mathrm{H}_{12}, 10^{-5}, \mathrm{mg} / \mathrm{m}^{3}$ & \multirow{2}{*}{ Fuel oil } & 38.5 & 31.5 \\
\hline $\mathrm{C}_{20} \mathrm{H}_{12}, 10^{-6}$, ton/year & & 280.1 & 24.8 \\
\hline $\mathrm{C}_{20} \mathrm{H}_{12}, 10^{-5}, \mathrm{mg} / \mathrm{m}^{3}$ & \multirow{2}{*}{ Water fuel emulsion } & 18.0 & 12.0 \\
\hline $\mathrm{C}_{20} \mathrm{H}_{12}, 10^{-6}$, ton/year & & 130.7 & 9.4 \\
\hline \multicolumn{2}{|c|}{ Decreasing of $\mathrm{C}_{20} \mathrm{H}_{12}$ in gas phase, $\%$} & 53.2 & 62.0 \\
\hline
\end{tabular}

The reducing effect of water on the formation of benzo(a)pyrene in the gas phase was used in DKVR-4/13 and PTVM-30-type boiler units, Teplokommunoenergo, Bishkek city, by modifying fuel oil into water fuel emulsions [45, 46]. The main parameter of reducing the concentration of benzo(a)pyrene in the gas phase was water content in the fuel oil in the range of $10-15 \%$.

The homogenization and obtaining an inverse emulsion of the fuel-air mixture can significantly reduce the concentration of benzo(a)pyrene by creating cavitation effects based on the rotary pulsation apparatus [47], while polydisperse water fuel emulsions are obtained according to the developed process flowsheet shown in Fig. 5. Complete combustion of water fuel emulsions led to a radical decrease in the concentration of toxic substances (Table 5), including benzo(a)pyrene in the gas phase (Table 6).

Combustion of water fuel emulsions in DKVR4/13, PTVM-30M boilers allowed for a reduction in the concentration of benzo(a)pyrene in the gas phase from 53 to $62 \%$ by creating developed contact surfaces of phases (Table 6).

\section{Conclusions}

Benzo(a)pyrene-oxygen, benzo(a)pyrene-water, benzo(a)pyrene-water-oxygen systems were studied at the entropy maximum. Equilibrium compositions and concentrations of components, particles and their distribution in the gas phase at different temperatures $(\mathrm{T}=500-2500 \mathrm{~K})$ and ratios of gas-liquid flows were established. Calculations showed that condensed carbon and acetylene were reduced or even not detected in the $\mathrm{C}_{20} \mathrm{H}_{12}-\mathrm{H}_{2} \mathrm{O}-\mathrm{O}_{2}$ (1:10:1) system due to the presence of a sufficient amount of hydrogen. Burning water fuel emulsions $(90 \%$ fuel oil $+10 \%$ water) in small- and medium-capacity boilers reduced the benzo(a)pyrene content in soot particles of flue gases by about $62 \%$ by creating a developed contact surface of the interacting phases and total combustion of water fuel emulsions in the burning zone.

\section{Conflict of Interest}

The authors declare no conflict of interest.

\section{References}

1. LUKACHEV S.V., GORBATKO A.A., MATVEEV S.G. Formation and burning out of benzo(a)Pyrene from the combustion of hydrocarbon Fuels. Mashinostroenie. 152, Moscow, 1999. [In Russian].

2. LAVROV N.V., STASEVICH N.L., KOMIN G.M. On the mechanism of benzo(a)pyrene formation. Reports of the Academy of Sciences of the USSR. 6, 1363, 1972. [In Russian].

3. IVANITSKY M.S., GRIEG A.D, GRIEG S.A., FOKIN V.M. Physical-chemical processes of the mechanisms of benzo(a)pyrene formation during the combustion of hydrocarbon fuel. Vestnik Volgograd Architectural and Construction University- series: construction and architecture. 46, 27. 2012 [In Russian].

4. RICHTER H., HOWARD J.B. Formation of polycyclic aromatic hydrocarbons and their growth to soot - a review of chemical reaction pathways. Progress in Energy and Combustion Science. 26, 565, 2000.

5. LAWAL A.T. Polycyclic aromatic hydrocarbons. A review, Cogent Environmental Science. 1, 2017.

6. LUKACHEV S.V., MATVEEV S.G., ORLOV M.YU. Release of carcinogens from the combustion of hydrocarbon fuels. SGAU. 160, 2007. [In Russian].

7. MATVEEV C.G., CHECHET I.V. Construction of detailed kinetic schemes for the formation of five ring PAHs and their reduction for use in modern packages. Bulletin of the Samara State Aerospace University. 5 (29), 188, 2011 [In Russian].

8. IVANITSKY M.S., GRIEG A.D. The acetylene mechanism for the formation of benzo(a)pyrene when burning natural gas in boiler furnaces. Bulletin of Voronezh State Technical University. 10 (1), 110, 2014 [In Russian].

9. TOMAZ S., SHAHPOURY P., JAFFREZO J.L., LAMMEL G., PERRAUDIN E., VILLENAVE E., ALBINET A. Oneyear study of polycyclic aromatic compounds at an urban site in Grenoble (France): Seasonal variations, gas/particle partitioning and cancer risk estimation. Science of the Total Environment. 565, 1071, 2016.

10. KHAN M.F., LATIF M.T., LIM C.H., AMIL N., JAAFAR S.A., DOMINICK D., TAHIR N.M. Seasonal effect and source apportionment of polycyclic aromatic hydrocarbons in PM2.5. Atmospheric Environment. 106, 178, 2015. 
11. GIANELLE V., COLOMBI C., CASERINI S., OZGEN S., GALANTE S., MARONGIU A., LANZANI G. Benzo(a) pyrene air concentrations and emission inventory in Lombardy region, Italy. Atmospheric Pollution Research. 4 (3), 257. 2013.

12. HUSSEIN I. ABDEL-SHAFYA, MONA S.M. Mansour. Review on polycyclic aromatic hydrocarbons: Source, environmental impact, effect on human health and remediation. Egyptian Journal of Petroleum. 25 (1), 107, 2016.

13. HAN J., LIANG Y., ZHAO B, XING F., QIN L. Polycyclic aromatic hydrocarbon (PAHs) geographical distribution in China and their source, risk assessment analysis. Environmental Pollution. 251, 312, 2019.

14. LIU B., XUE Z., ZHU X., JIA C. Long-term trends (1990-2014), health risks, and sources of atmospheric polycyclic aromatic hydrocarbons (PAHs) in the U.S. Environmental Pollution. 220, 1171, 2017.

15. DAT N.D., CHANG M.B. Review on characteristics of PAHs in atmosphere, anthropogenic sources and control technologies. Science of The Total Environment. 609, 682, 2017.

16. PENG N., LI Y., LIU Z., LIU T., GAI C. Emission, distribution and toxicity of polycyclic aromatic hydrocarbons (PAHs) during municipal solid waste (MSW) and coal co-combustion. Science of The Total Environment. 565, 1201, 2016.

17. KIM Y.,. SEO Y.-K, BAEK S.-O. A statistical inference for concentrations of benzo(a)pyrene partially measured in the ambient air of an industrial city in Korea Atmos. Environ. 81. 92, 2013.

18. YAN W.-J., LIU M., LIU S. Simulations of the atmospheric benzo[a]pyrene in China using CMAQ model. Zhongguo huanjing kexue China Environ. Sci. 36 (6), 1681, 2016.

19. GENG C., CHEN J., YANG X., REN L., YIN B., LIU $\mathrm{X}$., BAI Z. Emission factors of polycyclic aromatic hydrocarbons from domestic coal combustion in China. Journal of Environmental Sciences. 26 (1), 160, 2014.

20. MA W.L., LIU L.Y., JIA H.L., YANG M, LI Y.F. PAHs in Chinese atmosphere Part I: Concentration, source and temperature dependence. Atmospheric Environment. 173, 330, 2018.

21. HSU W.T., LIU M.C., HUNG P.C., CHANG S.H. PAH emissions from coal combustion and waste incineration. Journal of Hazardous Materials. 318, 32, 2016.

22. JOSE M., SANCHEZ-MARTÍN A.M., CAMPOS P., MILLER A.Z. Effect of pyrolysis conditions on the total contents of polycyclic aromatic hydrocarbons in biochars produced from organic residues: Assessment of their hazard potential. Science of The Total Environment. 667, 578, 2019.

23. GRIEGA A.D., IVANITSKY M.S. Nitropyrenes unburned hydrocarbons in flue gases of boiler plants. Energy Saving and Water Treatment, 5, 72, 2014 [In Russian].

24. GRIEGA A.D., IVANITSKY M.S. Determination of the concentration of benzo(a)pyrene in the flue gases of lowpower boiler plants. Alternative energy and ecology. 4, 51, 2014 [In Russian].

25. LIU L., LIU Y., LIN J., TANG N., HAYAKAWA K., MAEDA T. Development of analytical methods for polycyclic aromatic hydrocarbons (PAHs) in airborne particulates: A review. Journal of Environmental Sciences. 19, 1,2007

26. RUBOL S., SILVER W.L., BELLIN A. Determination of benzo[a]pyrene and dibenzopyrenes in a Chinese coal fly ash certified reference material. Science of The Total Environment. 432, 37, 2012.

27. IVANITSKY M.S. Numerical modeling of the dispersion of benzo(a)pyrene emissions from fuel combustion plants. Alternative Energy and Ecology. 22, 70, 2015 [In Russian].

28. SINYAREV G.B., VATOLIN N.A., TRUSOV B.G. The use of computers for thermodynamic calculations of metallurgical processes. Science.153, 1982. [In Russian].

29. KEMELOV K.A, MAYMEKOV Z.K, SAMBAEVA D.A. Physical-chemical basis of thermal destruction of benz(a) pyrene and reducing their concentration in a gas phase. World Academy of Science, Engineering and Technology. 9 (9), 753, 2015.

30. TONG L., PENG C.-H., HUANG Z.-W., XU N.-B., HE J. Identifying the Pollution Characteristics of Atmospheric Polycyclic Aromatic Hydrocarbons Associated with Functional Districts in Ningbo, China. Jin Bulletin of Environmental Contamination and Toxicology. 103 (1), 34, 2019.

31. SHEN G., PRESTON W., EBERSVILLER S.M, WILLIAMS C., FAIRCLOTH J.W., JETTER J.J., HAYS M.D. Polycyclic Aromatic Hydrocarbons in Fine Particulate Matter Emitted from Burning Kerosene, Liquid Petroleum Gas, and Wood Fuels in Household Cookstoves. Energy Fuels. 31 (3), 3081, 2017.

32. DOMÍNGUEZ-MORUECO N., SCHUHMACHER M., SIERRA J., NADAL M., DOMINGO J.L. Assessment of PAH loss in passive air samplers by the effect of temperature. Atmospheric Pollution Research. 7, 142, 2016.

33. ERIKSSON A.C., NORDIN E.Z., NYSTROM R., PETTERSSON E., SWIETLICKI E., BERGVALL C., PAGELS J.H. Particulate PAH emissions from residential biomass combustion: Time-resolved analysis with aerosol mass spectrometry. Environmental Science and Technology. 48, 7143, 2014.

34. IVANITSKY M.S, GRIEGA A.D., VASILYEVA Yu.V. Protection of atmospheric air against emissions of benzo(a) pyrene when boilers of low power are operated. Ecology of Russia-Towards Innovation. 8, 69, 2013 [In Russian].

35. IVANITSKY M.S, GRIEGA A.D. Formation of benzo(a) pyrene in the combustion chamber of an energy boiler taking into account the influence of uneven distribution of temperature and concentration fields. Bulletin of Volgograd State Technical University. 18 (6), 89, 2014 [In Russian].

36. PAKPAHAN E.N. ISA M.H., KUTTY S.R. Effect of temperature on the formation and degradation of polycyclic aromatic hydrocarbons. International conference on emerging technologies and environmental science and engineering - India, 569, 2009.

37. GRIEGA A.D., IVANITSKY M.S. Cleaning the flue gases of boiler plants from benzo(a)pyrene emissions. Energy saving and water treatment. 2, 75, 2015 [In Russian].

38. AN Y.-Z., PEI Y.-Q., QIN J., ZHAO H., TENG S.-P., LI B., LI X. Development of a PAH (polycyclic aromatic hydrocarbon) formation model for gasoline surrogates and its application for GDI (gasoline direct injection) engine CFD (computational fluid dynamics) simulation. Energy. 94, 367, 2016

39. ABDULAZIZ H.E. Impact of Combustion of Water in Fuel on Polycyclic Aromatic Hydrocarbon (PAH'S) Precursors' Formation. International Scholarly and Scientific Research \& Innovation. 8, 664, 2011.

40. VERMA S.K., MASTO R.E., GAUTAM S., CHOUDHURY D.P., RAM L.C., MAITI S.K., MAITY S. 
Investigations on PAHs and trace elements in coal and its combustion residues from a power plant. Fuel. 162, 138, 2015.

41. WANG Y., RONG Z., QIN Y., PENG J., LI M., LEI J., SHIJIN S. The impact of fuel compositions on the particulate emissions of direct injection gasoline engine. Fuel. 166, 543, 2016.

42. TATARINOV V.V. BAZARSKY O.V., SHPILEVA E.V., TOMILOV A.A. The model of the dispersion of benzo(a) pyrene in the atmosphere and the estimation of the rate of its dry and wet deposition. Scientific notes of the Rostov State Hydrometeorological University. 37, 216, 2014 [In Russian].

43. AKIMOV A.V. GORYACHKIN V.U., POLOVETS YU.A. Reduction of soot and benzo(a)pyrene emissions when burning water fuel emulsions in boilers. Problems of ecology and energy saving in shipbuilding VI international science technical conference. 48, 2014 [In Russian].
44. GRIEGA A.D. IVANITSKY M.S. Reducing emissions of benzo(a)pyrene by injecting moisture into the zone of active combustion. Combustion technology. - Collection of scientific papers of the IV All-Russian Scientific Practical Conference. 230, 2013 [In Russian].

45. MAYMEKOV Z.K. Scientific basis for optimizing the processes of burning liquid fuel and recarbonization of water-salt systems. Ilim. 410, Bishkek, 2015 [In Russian].

46. IMANAKUNOV S.B. The Effect of Water in a Fuel Emulsion on the Formation and Reduction of NitrogenContaining Components of the Gas Phase. Ph.D. thesis. 137, Bishkek, 2000 [In Russian].

47. MAYMEKOV Z.K., LARIN A.N., BAGIMOV N.I., IMANAKUNOV S.B. A rotor-pulsation apparatus for emulsifying water droplets in fuel. Patent No. 146 of. 08.05. 1996. No. 960352.1. [In Russian]. 
